\title{
FAMILIAR KINSHIP? PALAEOGENETIC AND ISOTOPIC EVIDENCE FROM A TRIPLE BURIAL OF THE COGOTAS I ARCHAEOLOGICAL CULTURE (BRONZE AGE, IBERIAN PENINSULA)
}

\begin{abstract}
Summary. This paper examines the identification of kinship relations in archaeological multiple burials and advocates the application of different methods and lines of research to clarify such issues in relation to funerary practices. Recognizing family relationships - an important task in research on prehistoric societies - is especially complicated and interpretations have often been made without an adequate empirical basis. Bioarchaeological, isotopic and DNA analyses applied to the triple burial of Los Tolmos (Cogotas I archaeological culture, Iberian Bronze Age) have provided direct information on this issue. In this respect, the new results also imply the need to consider gender constructs in greater depth and to be more open-minded towards other forms of relationship in the past beyond the traditional heteronormative nuclear family.
\end{abstract}

\section{INTRODUCTION}

Apart from any anecdotal evidence it may provide, archaeological research into kinship seeks to characterize societies and discover the origin and historical variations of social forms. However, for various reasons, basically methodological and financial, prehistoric research has for a long time focused on a 'direct' interpretation of the archaeological record in social terms, and has proceeded in a simplistic way regarding kinship. In this way, remains of more than one individual in a single grave have been interpreted as evidence of a close relationship: a married couple in the case of skeletons of two adults of different sexes, or a nuclear family in the case of three skeletons of a male, female and child. A new approach, on the more solid basis of the biological dimension of kinship, is necessary to leave behind these simplistic assumptions, especially for a period like the Bronze Age when funerary practices in Europe are still not well understood. In the case of the Cogotas I archaeological culture particularly, kinship could have been an especially important factor in social structures.

The Cogotas I archaeological culture, our field of research within the Bronze Age societies in the Iberian Peninsula, was initially defined solely by finds of pottery in a particular style, and this 
has steadily been supplemented by work in such fields as metal artefacts and metallurgical techniques, population patterns and agriculture. ${ }^{1}$ Its geographical distribution in the interior of Iberia (Fig. 1), where numerous sites are known, mostly of the 'pit field' type (multi-component sites with abundant refuse pits), is concentrated in the 'North Sub-Meseta' or northern part of the Iberian Plateau, basically coinciding with the Douro River Basin, and also in a sector of the southern Sub-Plateau, especially in the middle valley of the River Tagus. The culture is now very clearly dated within the Bronze Age. The association of the pottery and bronze objects already indicated this, and a large number of radiocarbon dates have confirmed that it spanned from the nineteenth to twelfth centuries cal BC, divided into two sub-phases known as Proto-Cogotas I and Full Cogotas I, corresponding respectively to the regional Middle Bronze Age and Late Bronze Age.

The funerary evidence for this culture is not missing, but it is strikingly scant, as the total number of individuals known for such a long span of time does not reach a hundred. Within this chrono-cultural framework, characterized by the 'invisibility of the dead', such traits as the absence of formal cemeteries and typological heterogeneity in burial forms should be highlighted, as on occasions old megalithic tumuli were used and sometimes caves, particularly in the mountainous periphery of the Plateau. However, most of the few burials that are known are interments, generally individual and occasionally multiple, inside pits - either refuse pits or pits dug ad hoc. Another striking aspect is the absence of grave goods, with very rare exceptions (Delibes 1978). The deceased were usually placed in a flexed lateral decubitus position, with a certain tendency towards a different position for each sex, with males predominantly placed on their right side and females on their left side, possibly as part of gender identities. It should be added that the bioarchaeological study of the funerary sites shows the quantitative importance of secondary burials. These burials, including finds of partial human remains, either alone or accompanying primary deposits, seem to be the result of an elaborate funerary ideology, or rather, of a worldview with a complex idea of death, as some animal offerings are found in the graves and some deposits are even solely of animals. This peculiar evidence has led to a recent proposal (Esparza et al. 2012b) that the normal funerary ritual in the Cogotas I culture must have been the exposure of the bodies, while the pit burials could be explained within the funerary ideology as the consequence of a 'bad death' (Thomas 1982).

In an attempt to explore further the social aspects of the funerary sphere in Cogotas I, a series of research projects have combined archaeological, bioarchaeological, isotopic and palaeogenetic approaches (Esparza et al. 2012a). Here we present a first account of the isotope and palaeogenetic analyses performed on a burial attributed to the Cogotas I culture, discovered in the Spanish village of Caracena, where three individuals were buried simultaneously.

\section{LOS TOLMOS SITE AND TRIPLE BURIAL (CARACENA, PROVINCE OF SORIA)}

Excavated by A. Jimeno (see Jimeno 1984), this site is surrounded by a meander of the River Caracena, a tributary of the Douro. A high rock platform completely separates two sectors: Sector A, with remains of an MBA seasonal habitation site, and Sector B, where the triple burial studied here was found. The latter sector, which cannot be seen from the habitation site, seems to have been used repeatedly as a funerary area, as some late Roman burials have also been found there.

1 A good state of the art can be seen in Abarquero (2005), Rodríguez-Marcos and Fernández-Manzano (2012) and Abarquero et al. (2013). On the funerary aspect, vid. Esparza et al. (2012a). 

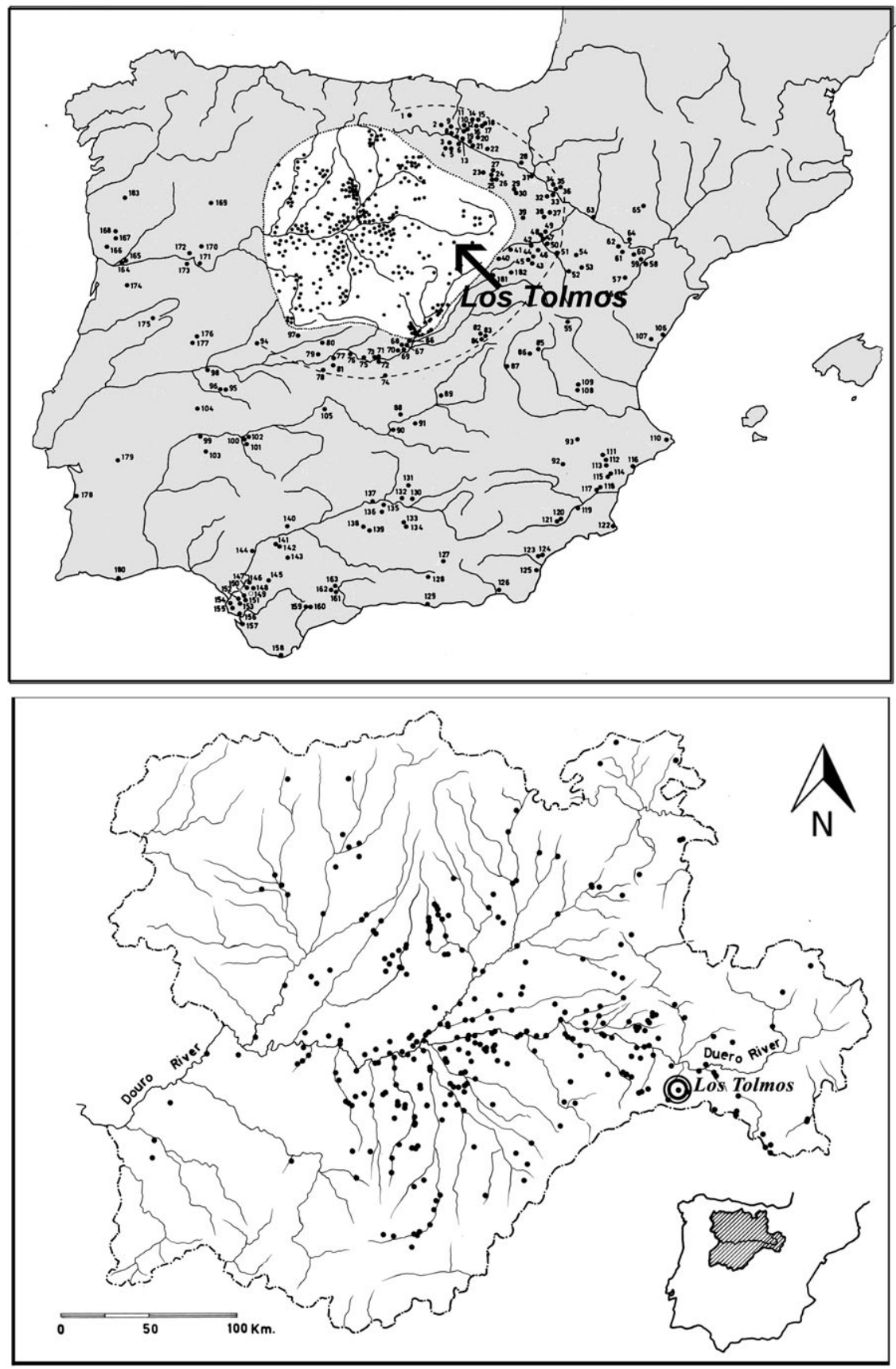

Figure 1

Top: map of the Iberian Peninsula showing the 'core area' of the Cogotas I archaeological culture (in light grey), its area of expansion and the extent of its influences, and the location of the site of Los Tolmos (after Abarquero 2005). Bottom: map of the modern autonomous region of Castile and Leon, with the distribution of sites dated to the Proto-Cogotas I phase. 
The 1979 archaeological fieldwork uncovered a pit whose limits were poorly defined, having been disturbed by a late Roman grave. It contained two adult skeletons in an almost lateral decubitus position, on their right and left sides; together with the first glance at their skulls, this suggested that they were a male and female respectively. Furthermore, remains of a perinatal individual were found between the lower limbs of the two adults. No grave goods accompanied the bodies, but the scarce archaeological material in the overlying layer, and above all a radiocarbon determination, meant that the burials could be assigned to the Proto-Cogotas I sub-phase.

Individual number 1 (LTB-01) can be classified as a female by the morphological features of the skull and the pelvis, and must have died between 20 and 25 years of age, according to the degree of ossification of the sternum end of both clavicles, the appearance of the pubic symphysis and the degree of wear on the molar occlusal surfaces (Buikstra and Ubelaker 1994).

Individual 2 (LTB-02) died between 30 and 40 years of age, judging by the wear on the surviving teeth and the degree of obliteration of the cranial sutures (ibid.). As noted above, the first impression was that this individual was a male, above all because of the marked dimorphism between its skull and that of Individual 1, and this was the sexual diagnostic proposed in the first publication (Garralda and Galera 1984, 346-7). However, our new bioanthropological study has recognized female traits in the skull and this new sex determination was corroborated by discriminating measurement criteria applied to the post-cranial skeleton (Alemán et al. 1997). Therefore it is now proposed that this individual is a female too.

Finally, the perinatal individual (LTB-03) mentioned in the first publication has been reexamined, both through analysis of the tiny bones that have been conserved and from the photographs taken during the excavation, which clearly identify its position relative to the female LTB-01, presumably its mother. Although the anatomical representation is partial, mainly because of taphonomic processes and also the process of the archaeological fieldwork itself, it can be established that this perinate died at between 37 and 39 weeks of gestation (Scheuer and Black 2000). It is therefore a terminal foetus, and it only remains to be determined whether its death occurred in the course of gestation or immediately after its birth; as explained below, the first possibility is the most plausible.

\section{THE FUNERARY DEPOSIT}

Bioarchaeological details allow the funerary sequence to be reconstructed in detail. Initially, the two adult individuals were placed symmetrically, back to back, with only their pelvises touching. This contact between the ilia, recorded during the excavation, attests to the simultaneity of their burial and the intentionality of this arrangement (Fig. 2).

The female LTB-01 must have been originally placed in a left lateral decubitus position, but later the body moved to a practically dorsal position. The legs were flexed in very different ways, perhaps because of her state of pregnancy. They maintained their lateral position, but the thoracic and sacrum regions moved, as did the head and left arm, resulting in the disconnection of the right sacroiliac articulation, the separation of the pelvis and femur, and the separation of the ulna and radius from the humerus. The study of the skeleton suggests that the body of this female was covered by a perishable object which, although resistant for a certain time and stopping or slowing down the entry of sediment considerably, allowed the movements observed during the decomposition process. In addition, there must have been an espace vide secondaire (secondary empty space), the term used for the result of the decomposition of a 'funerary cushion' or similar 

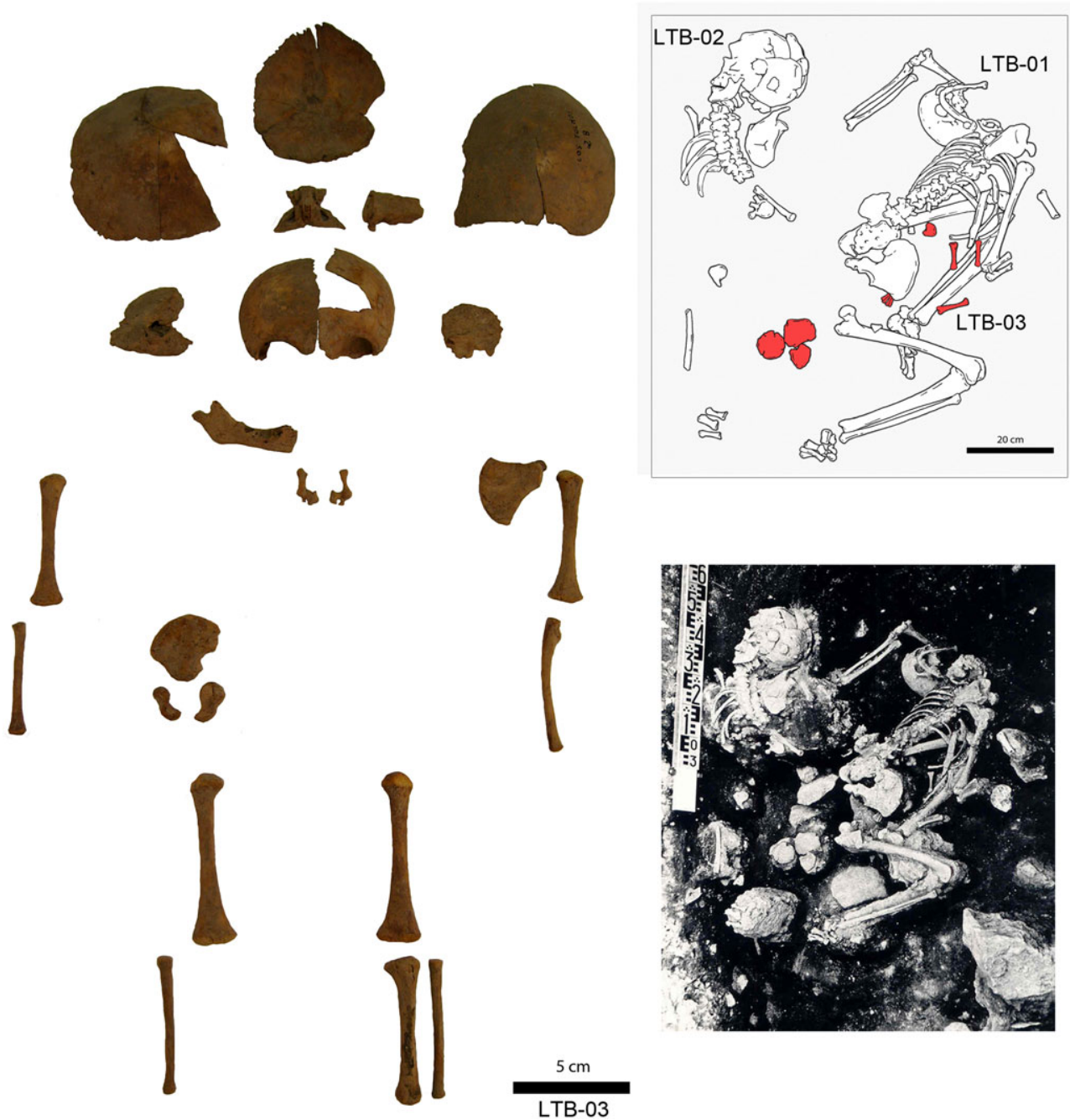

Figure 2

Left: preserved remains of the perinatal LTB-03; Right, below: photograph taken during the archaeological excavation (courtesy of A. Jimeno); Right, above: identification of the three individuals in the grave. [Colour figure can be viewed at wileyonlinelibrary.com]

object, for example made of wood (Duday 2005, 181). In this case, the female must have been placed with her head - probably on her flexed left arm - resting on such an object, which meant that at a later time the cranium turned and moved sideways when the object decomposed.

Individual LTB-02, considerably less well preserved, must have undergone a similar process. This second female was probably placed on her right side, since her skull and cervical vertebrae were found in that position, while her whole thoracic region turned and was found in a prone position during the excavation. This could also be explained by a decomposition process in an empty space (ibid.). 
Furthermore, the way that certain anatomical parts of each skeleton moved suggests that they were not covered individually but that both bodies were protected, possibly by a thick cover of intertwined branches, which only slowly allowed the entry of the sediment used to fill the grave.

The spatial relationship between the remains of the young female (LTB-01) and the terminal or perinatal foetus (LTB-03), as well as their genetic link (as explained below) poses certain questions about the nature of their archaeological association. With the available information, it does not seem unreasonable to add Los Tolmos to the growing list of archaeological examples of females dying in the last moments of pregnancy. Although few cases have been published, increasingly precise archaeological recording has, in recent years, led to the reporting of the burials of pregnant women in very different chronological and cultural contexts (Malgosa et al. 2004; De Miguel 2008; Cruz and Codinha 2009; Willis and Oxenham 2011; etc.). These precedents provide criteria for the study and explanation of this kind of burial, as well as for the precautions involved in its taphonomic assessment and the problems associated with its cultural appraisal. However, it is extremely difficult to approach these aspects in the case of Los Tolmos, where only the illustrations produced during the original fieldwork and the results from the recent anthropological study are available.

The first remarkable point, apart from the age of death of the mother and child, is the relative position of the remains of the perinatal individual and the young female. While it is true that portions of the perinatal skull were recorded very close to the proximal end of the right femur, between the two adults, most of the infant's bones were recorded in the region between the pelvis bones, left leg and right arm of LTB-01; this would be precisely the area where the remains of the foetus would be expected if the female had indeed been pregnant. In this respect, it may also be ventured that the position given to the woman, especially the asymmetric position of her legs, may reflect the advanced state of her pregnancy at the time of her burial. However, the general lack of anatomical connections in the infant, the skeletal under-representation and the particular distribution of the remains in the deposit make it difficult to determine whether the female was really pregnant when buried or, as proposed in some other cases (Lewis 2007, 35), the newly-born child was placed near or over the woman's belly when they were buried. Nonetheless, some evidence exists to clarify this issue.

Some of the remains of the perinatal individual, especially the lower limb bones, were located on the woman's left tibia and fibula, whereas the right ilium was found very near to the posterior face of her right femur. However, the most eloquent evidence is that four metacarpals or metatarsals of the infant, apparently in a strict anatomical position, were identified beneath the woman's right pelvis. This shows that it is very likely that the foetus was still in its mother's womb at the time of the burial, as that is the only explanation for some of its bones being trapped under one of its mother's pelvic bones, especially bearing in mind the different decomposition rates of each individual. This circumstance, together with the conditions in which the bodies naturally degraded, may help to explain why the perinatal remains moved so far.

As stated above, the decomposition process took place in a secondary empty space, the grave, which allowed movements of varying degree even beyond the space originally occupied by the bodies, as seen in the case of the two adults. This could explain the relatively wide dispersal of the infant's bones, owing to the protection provided by the mother's placenta and body, which delayed the entry of sediment (Alduc and Blondiaux 2002, 298-301; Cruz and Codinha 2009, 12). However, in this case a further two basic points should be taken into account. First, the skeletization rate is normally faster in infants than in adults (Lewis 2007, 23), which implies greater speed in the disarticulation of anatomical connections of the foetus in an 'empty space'. Second, in pregnant women, the gases generated during the decomposition process tend to expel the placenta, 
TABLE 1

Radiocarbon dates for the three individuals from Los Tolmos

\begin{tabular}{llr}
\hline Sample & Lab. reference & Radiocarbon date \\
\hline LTB-01 & Poz-31726 & $3520 \pm 35 \mathrm{BP}$ \\
LTB-02 & Poz-31727 & $3500 \pm 35 \mathrm{BP}$ \\
LTB-03 & Poz-31729 & $3550 \pm 35 \mathrm{BP}$ \\
\hline
\end{tabular}

and with it, the remains of the child (Alduc and Blondiaux 2002; Pinheiro 2006; Lewis 2007; Cruz and Codinha 2009). These two phenomena, especially considering the size, weight and shape of foetal bones, may explain the location of the cranial portions of the terminal foetus and, in general, the wide dispersal of its skeletal remains in the deposit.

\section{RADIOCARBON DATING OF THE BURIAL}

As part of our research protocol, bone samples of the three individuals have been dated by the AMS method at Poznan Radiocarbon Laboratory. The results are given in Table 1. As the burials were simultaneous (which is particularly clear in the case of the mother and her baby), the three dates can be regarded as representing a single event and this can be taken as prior information for

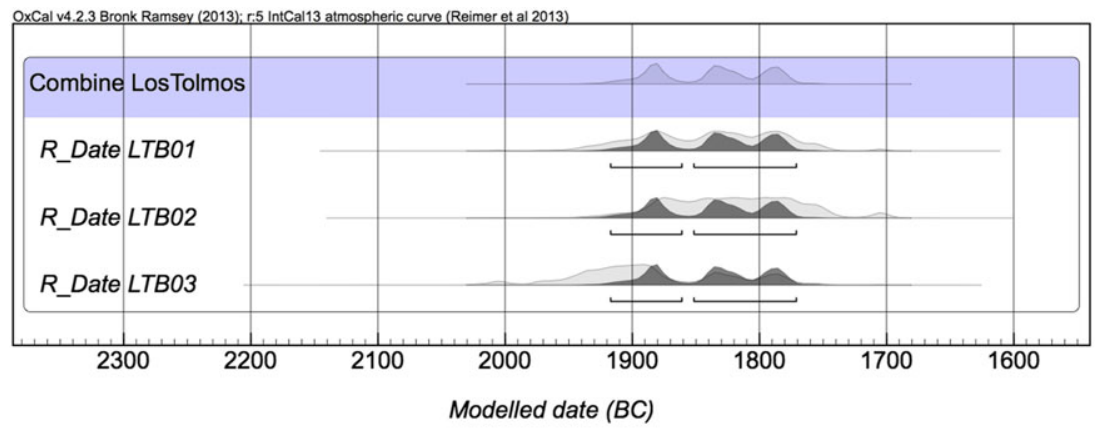

\begin{tabular}{|c|c|c|c|c|c|c|c|c|c|c|c|c|}
\hline \multirow{2}{*}{$\begin{array}{l}\text { Name } \\
\text { Show all } \\
\text { Show structure }\end{array}$} & \multicolumn{4}{|c|}{$\begin{array}{l}\text { Unmodelled } \\
\text { 洰 (BC/AD) }\end{array}$} & \multicolumn{3}{|c|}{$\begin{array}{l}\text { Modelled } \\
\text { (BC/AD) }\end{array}$} & \multicolumn{3}{|c|}{ Indices } & \multirow{2}{*}{$\begin{array}{l}\text { Select } \\
\text { All } \\
\text { Visible }\end{array}$} & \multirow{2}{*}{$\begin{array}{l}\text { Page } \\
\text { break }\end{array}$} \\
\hline & & from & to & $\%$ & from & to & $\%$ & Acomb & A & L P C & & \\
\hline $\begin{array}{l}\text { Combine } \\
\text { LosTolmos }\end{array}$ & 㭅 & -1918 & -1772 & 95.4 & & & & 106.4 & & & $\nabla^{2}$ & $\square$ \\
\hline R_Date LTB01 & 㭅 & -1939 & -1749 & 95.4 & -1918 & -1772 & 95.4 & & 118 & & $\nabla^{3}$ & $\square$ \\
\hline R_Date LTB02 & 㭅 & -1919 & -1700 & 95.4 & -1918 & -1772 & 95.4 & & 105 & & $\nabla 4$ & $\square$ \\
\hline R_Date LTB03 & 㭅 & -2011 & -1771 & 95.4 & -1918 & -1772 & 95.4 & & 89.9 & & $\nabla 5$ & $\square$ \\
\hline
\end{tabular}

Figure 3

Bayesian model for the Los Tolmos burial dates: For each of the dates two distributions have been plotted: one, in outline, is the result of simple radiocarbon calibration; the second, solid distribution, is based on the chronological model used (OxCal online Radiocarbon Calibration). [Colour figure can be viewed at wileyonlinelibrary.com] 
Bayesian treatment. The OxCal v.4.2.3 program (Bronk Ramsey 2009), which uses the IntCal 13 atmospheric curve (Reimer et al. 2013), is able to model this situation with the Combine option and obtain the posterior distribution, as shown in Fig. 3. The mortuary event would thus have occurred between 1918 and $1772 \mathrm{cal} \mathrm{BC}$ (agreement index a =106.4), which is to say, in a period of time around the nineteenth century cal BC, in the oldest part of the Proto-Cogotas I phase.

\section{ISOTOPIC STUDY}

\section{Palaeodietary isotopic reconstruction}

A commonly used method for reconstructing past human diets is the analysis of carbon and nitrogen stable isotope ratios (e.g. Lee-Thorp 2008). The isotopic composition of food eaten by human and non-human animals is recorded in their body tissues after a predictable isotope fractionation, and this is the main principle on which this technique is based (Schoeller 1999). Mainly because it is the only considerable nitrogen source preserved in skeletal remains, bone collagen is usually the preferred substrate for these analyses (Salazar-García et al. 2014a). Furthermore, collagen has accepted quality indicators that can easily be used to assess its isotopic integrity (De Niro 1985; Van Klinken 1999). Stable isotope ratios in bone collagen reflect the average isotopic signals of the main dietary protein sources consumed several years prior to death (Hedges et al. 2007), rather than the diet over the whole lifespan, especially for nitrogen (Ambrose and Norr 1993). The relative abundance of stable carbon isotopes ${ }^{13} \mathrm{C}$ and ${ }^{12} \mathrm{C}\left(\delta^{13} \mathrm{C}\right)$ distinguishes the consumption of $\mathrm{C}_{3}\left({ }^{13} \mathrm{C}\right.$ depleted) and $\mathrm{C}_{4}\left({ }^{13} \mathrm{C}\right.$ enriched) terrestrial resources (Van der Merwe and Vogel 1978). It also helps to define the input of terrestrial $\left({ }^{13} \mathrm{C}\right.$ depleted) and marine $\left({ }^{13} \mathrm{C}\right.$ enriched) foods to the diet (Chisholm et al. 1982). The interpretation of $\delta^{13} \mathrm{C}$ values becomes more complicated if brackish water fish was included in the diet (Salazar-García et al. 2014b). The $\delta^{15} \mathrm{~N}$ stable isotope ratio increases by 3-5\% up the food-chain with each trophic level, and is usually used to indicate the position of an organism in the food chain (Minagawa and Wada 1984). Based on the exact values of the nitrogen ratio, it is potentially possible to differentiate between individuals who consumed more animal resources and those who consumed very little animal protein (e.g. Fahy et al. 2013), even if this quantification is less straightforward than previously thought (Hedges and Reynard 2007). Furthermore, the fact that aquatic food chains tend to contain more trophic levels than terrestrial ones allows the detection of aquatic foods in the diet (Schoeninger and De Niro 1984) and helps carbon isotope ratios to discriminate between the consumption of marine or $\mathrm{C}_{4}$ terrestrial foods when samples are ${ }^{13} \mathrm{C}$ enriched.

\section{Material and Methods}

Bone samples from the three individuals were taken for analysis. Prior to analysis, visible contaminants were removed with aluminium oxide powder abrasion. Collagen extraction proceeded following Richards and Hedges (1999), with the addition of an ultrafiltration step (Brown et al. 1988). To summarize, whole bone pieces of c.300 $\mathrm{mg}$ from each of the fragments were demineralized in $0.5 \mathrm{M} \mathrm{HCl}$ solution at $5^{\circ} \mathrm{C}$ over the course of one week, and were then rinsed three times with deionized water until the $\mathrm{pH}$ became neutral. This was followed by gelatinization over 48 hours at $70^{\circ} \mathrm{C}$, and later by filtering with a $5 \mu \mathrm{m}$ EZEEC filter and ultrafiltering with 
$>30 \mathrm{kDa}$ Amicon@ $@$ ultrafilters. The purified solution was finally frozen and lyophilized before being weighed into tin capsules and loaded into the mass spectrometers.

The carbon and nitrogen isotope ratios in collagen were measured in duplicates using a Delta XP continuous-flow isotope ratio mass spectrometer after being combusted in an elemental analyzer Flash EA 2112 that was interfaced with it (Thermo-Finnighan $@$, Bremen, Germany) at the Max-Planck Institute for Evolutionary Anthropology (Leipzig, Germany). Stable carbon isotope ratios were expressed relative to the VPDB scale (Vienna PeeDee Belemnite) and stable nitrogen isotope ratios were measured relative to the AIR scale (atmospheric $\mathrm{N}_{2}$ ), using the delta notation $(\delta)$ in parts per thousand $(\% o)$. Repeated analysis of internal and international standards determined an analytical error better than $0.1 \%$ o $(1 \sigma)$ for $\delta^{13} \mathrm{C}$ and $\delta^{15} \mathrm{~N}$.

\section{Results}

The stable isotope results for the humans from Los Tolmos are presented in Table 2. Collagen samples from femurs of the three individuals (two adults, one perinatal) buried together were analyzed. All samples yielded enough collagen at the $>30 \mathrm{kDa}$ fraction for analysis in duplicate, met the published collagen quality indicators $(\% \mathrm{C}, \% \mathrm{~N}, \mathrm{C}: \mathrm{N}$ ratio), and had a collagen yield higher than 2\% (Ambrose 1990). Since there were no contemporary faunal remains available at the site for comparable analysis, interpretation of the human values is limited.

The two adult $\delta^{13} \mathrm{C}(-19.2 \%$ and $-19.5 \% \circ)$ and $\delta^{15} \mathrm{~N}(9.2 \% \circ$ and $8.3 \%$ ) values suggest a diet based on terrestrial $\mathrm{C}_{3}$ resources, with no clear isotopic evidence for any marine or freshwater protein consumption. Assuming, as suggested by field anthropology, that the mother died while still pregnant, the perinatal individual could be treated as 'another of her tissues' and its isotope composition would be the result of the mother's diet. However, although still very similar, the perinatal $\delta^{13} \mathrm{C}\left(-18.5 \%\right.$ ) and $\delta^{15} \mathrm{~N}(10.0 \%$ ) values are both slightly positively shifted from those of the biological mother $\left(-19.2 \%\right.$ and $9.2 \%$ respectively), in $0.7 \% \circ$ on $\delta^{13} \mathrm{C}$ and $0.8 \%$ in $\delta^{15} \mathrm{~N}$. This slight increase is most likely due to the different dietary averaging effects on the collagen (the mother's collagen would reflect the diet for several years prior to death, while the perinatal's collagen would reflect the diet of the mother's last months of life), as well as a potential unknown isotopic fractionation occurring between mother and child.

\section{PALAEOGENETIC STUDY}

Following the research project protocol, samples were taken for palaeogenetic analysis, initially oriented toward the hypothesis that the buried individuals were the members of a single family unit. Two samples from each of the three skeletons (adult teeth and perinatal humerus)

TABLE 2

Los Tolmos $\delta^{13} \mathrm{C}$ and $\delta^{15} \mathrm{~N}$ human values, collagen control indicators (yield, $\% \mathrm{C}, \% \mathrm{~N}, \mathrm{C}: \mathrm{N}$ ), S-EVA number, and archaeological code

\begin{tabular}{llcccccccc}
\hline S-EVA & \multirow{2}{*}{ Archaeological Code } & Sex & Age (yo) & $\boldsymbol{\delta}^{\mathbf{1 3}} \mathbf{C}(\boldsymbol{\%})$ & $\boldsymbol{\delta}^{\mathbf{1 5}} \mathbf{N}(\boldsymbol{\%})$ & Yield (\%) & $\boldsymbol{\%} \mathbf{C}$ & $\boldsymbol{\%} \mathbf{N}$ & $\mathbf{C}: \mathbf{N}$ \\
\hline 11168 & LTB-01 & Female & $22-26$ & -19.2 & 9.2 & 2.4 & 40.1 & 14.6 & 3.2 \\
11169 & LTB-02 & Female & $25-40$ & -19.5 & 8.3 & 2.6 & 39.0 & 14.0 & 3.3 \\
11170 & LTB-03 & Female & perinatal & -18.5 & 10.0 & 5.1 & 43.1 & 15.8 & 3.2 \\
\hline
\end{tabular}


allowed the extraction and amplification of nuclear and mitochondrial DNA, yielding reliable results (replicated and cloned in the case of mtDNA) regarding possible relationships (maternal lineage and close kinship) and the molecular sex of the individuals.

\section{Methodology}

We attempted to select at least two samples from each skeleton's teeth, in the case of the adults, and a humerus of the perinatal individual, in order to replicate the experimental process. Before the DNA extraction, the samples were cleaned to remove contaminant DNA molecules from the outer surface, and gridded. The DNA extraction was performed according to the usual protocol (Rohland and Hofreiter 2007a, 2007b; Rohland et al. 2009), with $500 \mathrm{mg}$ of bone or tooth powder from each sample. The next step was the DNA amplification; different markers within the nuclear DNA and mitochondrial DNA were amplified. The mitochondrial DNA amplification was carried out with four pairs of primers (two primers (Fernández 2005) to amplify 293 base pairs of HVI by the amplification of two overlapping fragments, and other two (Martínez-Labarga and Rickards 1999) to amplify 376 base pairs of HVII by two different overlapping fragments), using a Multiplex PCR kit (Qiagen (®). The autosomal DNA amplification was performed with three different forensic STR amplification kits (at least twice with each of the three kits).

After the mitochondrial and autosomal DNA amplification, consensus mitochondrial and autosomal profiles were defined from the multiple sequences obtained (Palomo-Díez et al. 2015). All the final results are summarized in Tables 3, 4 and 5.

The full experimental process was carried out in the Laboratory of the Forensic and Population Genetics Group (Complutense University of Madrid) following the criteria of authenticity for ancient DNA: genetic analyses were performed in specialized ancient DNA laboratories. Pre-PCR, PCR and post-PCR procedures were performed in three physically separated and isolated areas. DNA laboratories were equipped with UV light lamps. Additionally, work and laboratory equipment was routinely cleaned with bleach and UV-irradiated before and after each experiment. Access to these laboratories was limited to three people. To reduce staff DNA contamination, the whole experimental process was conducted by a single researcher who always wore disposable coveralls (special clothes, masks, caps, glasses, shoe covers and gloves). To avoid the presence of molecular damage, only the replicable results were considered valid, carrying out at least two amplifications of each mtDNA fragment from each sample. To consider a result valid, the sequences of different amplifications from the same sample and from the two different samples of the same individual must be exactly alike. Furthermore, bacterial cloning was used to authenticate mitochondrial sequences; at least twelve different clones from each sequence were obtained, without any sign of molecular damage. Further information will be available in Palomo-Díez et al. (in preparation); only the data and results necessary for this archaeological discussion will be mentioned here.

Mitochondrial DNA profiles of the three individuals

\begin{tabular}{cc}
\hline INDIVIDUAL & HAPLOTYPE mtDNA \\
\hline LTB-01 & $16224 \mathrm{C}, 16311 \mathrm{C}, 16362 \mathrm{C}$ \\
LTB-02 & $16224 \mathrm{C}, 16311 \mathrm{C}$ \\
LTB-03 & $16224 \mathrm{C}, 16311 \mathrm{C}, 16362 \mathrm{C}$ \\
\hline
\end{tabular}


ÁNGEL ESPARZA ET AL.

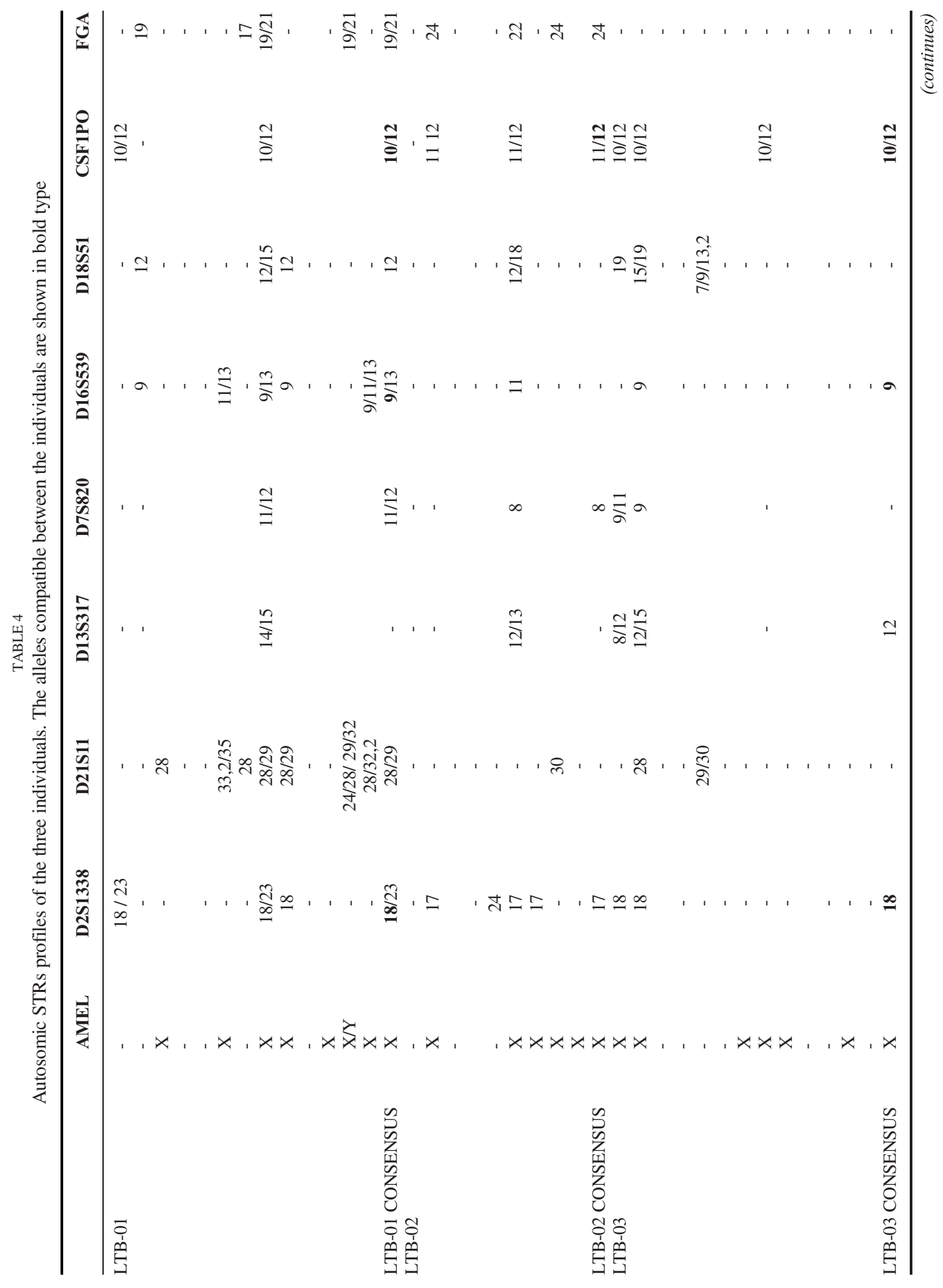




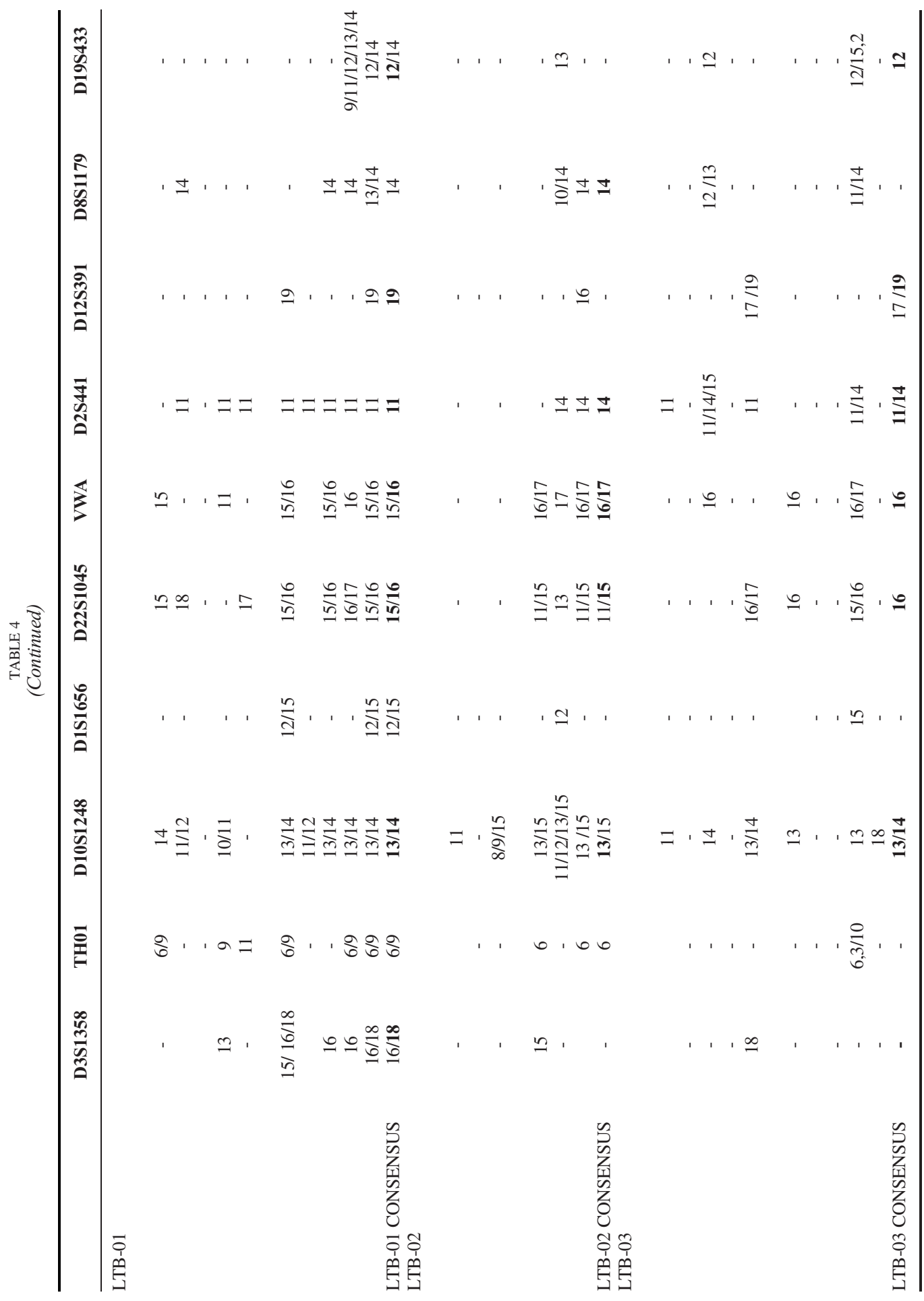


TABLE 5

Kinship analysis developed with Familias version 1.97

\begin{tabular}{cccc}
\hline Type of kinship & INDIVIDUALS & Likelihood Ratio & Probability of kinship \\
\hline Mother-Daughter & LTB-01/LTB-03 & 1427,57 & $99.93 \%$ \\
Sister-Sister & LTB-01/LTB-03 & 150,77 & $99.34 \%$ \\
Aunt-Niece (by the paternal line) & LTB-02/LTB-03 & 0,1317 & $11.64 \%$ \\
Grandmother-Granddaughter (by the paternal line) & LTB-02/LTB-03 & 0,1317 & $11.64 \%$ \\
Aunt-Niece (by the paternal line) & LTB-02/LTB-01 & 0,045 & $4.34 \%$ \\
Grandmother-Granddaughter (by the paternal line) & LTB-02/LTB-01 & 0,090 & $8.31 \%$ \\
\hline
\end{tabular}

mtDNA analysis

As shown in Table 3, the LTB-03 and LTB-01 individuals share the same mtDNA profile, suggesting a relationship through the maternal line. This result is compatible with the kinship already indicated by the bioanthropological study, a mother-child relationship. In contrast, LTB02 lacks the $16362 \mathrm{C}$ mutation present in the other two and cannot belong to the same female lineage, unless this were a 'private' mutation occurring only in this individual.

\section{Nuclear DNA analysis}

Table 4 shows the partial nuclear DNA genetic profiles obtained from each amplification, and the final consensus profile with matched alleles between individuals marked in bold, including also sex determination by amplifying a fragment of the amelogenin gene, which allowed the identification of all three individuals as females.

The possible kinship relationships between the three individuals have been calculated from nuclear markers (Table 5). The clearest result is between LTB-01 and LTB-03, for which a motherhood relationship is slightly more likely than sisterhood.

As we have seen, kinship through mother lineage between LTB-02 and the other two individuals is excluded as they do not share the same mitochondrial haplotype. Therefore, other possible relationships were considered, for example paternal grandmother-granddaughter or paternal aunt-niece. The results are not definitive, since the degree of coincidence is very small: the most interesting possibility, that LTB-02 was the paternal grandmother (or aunt) of LTB-03, is inconclusive; while the possibility cannot be ruled out, there is not sufficient basis to confirm it (probability $=11.64 \%$; LR $=0.1317$ ). The probability of a relationship between the two adult females is even lower.

\section{Palaeogenetic conclusions}

In short, genetic sex determination demolishes the initial suspicion that the group could be a nuclear family (man, woman and perinatal), since the alleged male individual has proved to be female. It was also possible to identify the perinatal individual LTB-03 as a female, which is important because genetics is the only way to determine sex in this case. Regarding kinship, the mother-child relationship between LTB-01 and LTB-03 is certified (99.93\% probability). In contrast, the mature female (LTB-02) is maternally unrelated to the other two, and nor is patrilineal 
kinship clear, although it cannot be completely ruled out that she was the paternal grandmother or aunt of the perinate.

\author{
DISCUSSION
}

\title{
Cause of death
}

The interesting question of the causes of death of the individuals cannot be clarified (except, of course, in the case of the foetus in its mother's womb) due to the lack of evidence in the archaeological and osteological records.

The cause of death for the female LTB-01 is somewhat ambiguous; the birth had not taken place or there was perhaps an obstructed labour (dystocia). This could be one of those cases of 'maternal death' common in traditional societies, owing to a complication in the last weeks of the pregnancy, but might equally be a 'non-obstetrical death', resulting from an accident, aggression or some other cause. Although there is no evidence of this on the skeletons, the cause of death would seem to be of the second kind, principally because of the presence of the elder female in the grave, who probably died together with the pregnant female as a consequence of the same exceptional event.

\section{The mortuary rite: regularity within the exceptional}

This triple burial has to be integrated within the framework of mortuary practices in the Cogotas I culture. As noted earlier, it has been proposed that the exposure of bodies was the normal funerary practice in this culture, while burials in pits were reserved for those individuals whose death or its circumstances might be regarded as anomalous or special ('bad death') (Esparza et al. 2012b). It has equally been shown that the demographic profile of the individuals in Cogotas I pit burials is characterized, among other traits, by a high number of females (nearly twice as many as males) who died between 20 and 40 years of age (Esparza et al. 2012a, 296). It has been pointed out that, as in other pre-industrial societies, these high numbers might be understood as a direct consequence of problems arising during pregnancy, while giving birth, or in successive pregnancies, which are specific to this segment of the population. It should be added that LTB-03 is, among the individuals in Cogotas I burials, the only one known to have died at under one year of age, which corroborates the exceptional circumstances of this burial, especially when bearing in mind the mortality rates that might be expected at that time. It would have been because of this special nature of the deaths, perhaps in a dystocial birth or an accident, that these individuals received mortuary treatment that was not the normal practice but was instead reserved for 'other deaths'.

Pregnancy and childbirth were circumstances which often caused the death of women and, additionally, a wide range of causes can result in the death of mother and child together. It is not surprising that many cultures, for example in the Classical world (Alfayé 2009; Iriarte 2009) or traditional African societies (Thomas 1982, 102, 105; Bonnet 1988, 72), have treated this as a special category, receiving different burial treatment from that given to the population in general. As one illustration of this distinction in African societies, it may be recalled that in pre-colonial Ghana, whereas families buried their dead in their own domestic compounds because to leave them in a cemetery would be to abandon them to the spirits of the forest, the bodies of "the wretched, such 
as witches and women who died in childbirth" were buried in land outside the compound walls (Roberts 2011, 214).

It is true that the mortuary ideology of 'good' and 'bad' death is not universal and can take numerous forms and names, but several scholars have agreed in seeing it as a cross-cultural phenomenon (Weiss-Krejci 2011, 70). It is suggested here that within the Cogotas I mortuary ideology the kind of death documented at Los Tolmos would have been considered special, and for that reason, this mother with her terminal foetus was buried in a pit, accompanied by another, older female with whom their relationship is unclear.

\section{The hypothesis of the nuclear family}

In the case of Los Tolmos, where the three skeletons were initially classified as male, female and perinatal, the palaeogenetic verification of the hypothetical identification of the group as a traditional nuclear family might have appeared unnecessary. However, the need for verification was framed within a scientific debate of great significance. Indeed, some critical voices (e.g. Castro et al. 1993-94) had already been raised against such simplistic interpretations, not without their ideological baggage. To give an example, in another of the great Bronze Age cultures in the Iberian Peninsula, the El Argar culture, the frequent occurrence of double graves of a male and female had been interpreted since the time of the scholar Siret as proof of the existence of monogamous marriage and the nuclear family. However, some researchers have used more recent radiocarbon determinations to propose that the members of these supposed married couples in fact belonged to very different generations, and that the relationship between the deceased was of descent and not marriage. Moreover, as the first to be buried was often the woman, researchers have proposed that the social framework of these graves was the extended family based on matrilineal lineages (ibid., 89; Lull 1997-98, 72).

As in other research on the Copper and Bronze Ages, our initial approach to this topic in the Cogotas I culture also supposed that triple burials - which were simultaneous, unlike the Argaric burials - would correspond to nuclear families (Esparza 1990, 126). Now, in contrast with the initial appearance of the burial, the results of the palaeogenetic study exclude the hypothesis that an heteronormative family was interred at Los Tolmos. However, this negative conclusion should not be generalized either, as there may be positive cases, such as at San Román de Hornija, which is still pending definitive results. The most important point is that each archaeological 'document' contributing to research into prehistoric societies should be 'transcribed' with the utmost rigour.

\section{A unique grouping}

If, as has been shown, the Los Tolmos burial did not contain an heteronormative nuclear family, how can such an unusual case be explained? It seems that the grave held two biologically unrelated adult females, unlike the normal pattern in these cases, when related people were usually buried together. Several explanations may be put forward.

When this case has been presented informally in different contexts (comments made with other researchers, at seminars, etc.), it has often been suggested that all three individuals died in a single event; for example a pregnant woman and her step-mother or mother-in-law were killed in a domestic accident. An even more extreme scenario has sometimes been suggested: the older woman was the midwife, who was killed for having failed in attending the childbirth in which the 
young woman and her baby died. Since it is very difficult to verify these proposals, it may be preferable to search in other directions, for example under the influence of current gender issues: could this be another type of family, different from the nuclear family of father, mother and children?

Certainly, ethnographic research provides other possible solutions to the problem. In some Native North American societies, when women reached the menopause they took on a new social personality, a combination of female and male gender roles, and consequently they were able to behave in ways forbidden to younger women, such as to enter the 'Men's House', speak in assemblies, smoke a pipe, etc. (Anderson 2011, 130). Furthermore, some studies note the existence in some societies of a more complex typology of genders than the predominant dichotomy. Certain tribal societies like the Siberian Yakut, Alaskan Inuit and the North American Mohave, seem to have developed more complex classificatory systems, above all with four categories: these add mixed genders to the usual two, which can be described as man-woman and woman-man. These categories are based not so much on sexual orientation as personal preferences or occupations. Based on this evidence, well-documented anthropologically, in his research on the funerary practices in the Chalcolithic of Central Europe, Turek (2011) proposes that it is necessary to reconsider the perspectives on gender that are applied in the study of prehistoric societies, in an attempt to explain the enigmatic mixtures of identity he has identified in Bell-Beaker and Corded Ware burials. In a similar way, could it be proposed that at Los Tolmos the older woman was playing a 'paternal role'? It is extremely difficult to progress in this line of research, but it should be recalled that this female, whose skull initially was interpreted as that of a male, was placed in a right lateral decubitus position. In the world of Cogotas I, this seems to have been the most usual position for males (Esparza et al. 2012a, 281-2). It contrasts with the skeleton of the young mother who, as expected, was placed on her left side.

\section{CONCLUDING REMARKS}

This bioarchaeological study has been unable to determine exactly what happened to the females buried in this grave at Los Tolmos. It may be considered a simple accident that ended the lives of the two of them and the foetus that the younger one bore. Other possibilities cannot be ruled out, but these are more or less speculative, as is the identification of the role of the older woman (as mother-in-law, step-mother, midwife, paternal role, etc.). Whatever the truth, it seems to follow the prescriptive pattern in the Cogotas I culture; as it was some kind of 'bad death', the exceptional formula of burial in a pit, without grave goods and within the living area, was applied.

Finally, no less important are certain methodological consequences deriving from the present study. First, the usual interpretation of triple burials as an heteronormative nuclear family should be carefully avoided. Although the fact that occasionally they are indeed nuclear families should not be ignored, this must be proved and not assumed, especially now that attention has been drawn to the complexity of relationships between sexes and genders. Second, the study has been able to show the lack of kinship between the two adults and to demonstrate the mother-daughter relationship (which was also evident archaeologically), through the DNA analysis. With the evidence of the amelogenin gene, it has equally been possible to verify the sex of the three individuals, especially the perinate, whose sex could not be determined any other way. Sex determination is of vital importance in our project, in combination with other variables such as the position of the body, orientation, food markers, physical activity, state of health, etc., in order 
to recognize certain gender patterns. This objective must avoid the risk of projecting our present system of identities on the past.

It has also been possible to assess the isotopic correspondence between the foetus and its mother, which was to be expected given that the former was fed directly through the mother's placenta. Finally, the attainment of the mitochondrial DNA results is also significant within interpretations of the Cogotas I culture, which have stressed the importance of the movements of groups (transhumance, etc.) and individuals (especially women) to explain the wide spread of cultural patterns (Abarquero 2005). However, these previous interpretations had no access to palaeogenetic evidence, which is now becoming available.

\section{Acknowledgements}

We wish to thank the Spanish Ministry of Economy and Competitiveness for supporting this research financially (Projects HUM2005-00139/HIST, HAR2009-10105 and HAR2013-43851-P), and the Autonomous Government of Castile and Leon for the support of archaeological excavations and our museum-based research. We are grateful to Prof. Tomasz Goslar (Poznan Radiocarbon Laboratory) for the AMS dating, and to our friend Prof. Alfredo Jimeno (Universidad Complutense de Madrid), who very generously allowed us access to the human remains and supplied various information about the Los Tolmos site, as well as to Prof. Mike P. Richards, Prof. Jean-Jacques Hublin, Sven Steinbrenner and Annabell Reiner (Max Planck Institute for Evolutionary Anthropology, Leipzig). DCS-G acknowledges funding from the Generalitat Valenciana (VALi + d APOSTD/2014/123 and GV/2015/060), the BBVA Foundation (I Ayudas a investigadores, innovadores y creadores culturales) and the European Union (FP7/2007-2013-MSCACOFUND, n ${ }^{\circ} 45743$ via a Braudel-IFER-FMSH). Part of this work was funded by the Max-Planck Society.

\section{(ABAE) Departamento de Prehistoria, $H^{a}$ Antigua y Arqueología Universidad de Salamanca 37071, Salamanca, SPAIN (Corresponding author) E-mail: esparza@usal.es} (SP-D) Universidad Complutense de Madrid (JV-V) Universidad de Las Palmas de Gran Canaria (GD) Universidad de Valladolid (EA-P) Universidad Complutense de Madrid (DCS-G) Max Planck Institute for Evolutionary Anthropology Leipzig/GI Prehistoria IT622-13 Universidad del Pais Vasco-Ikerbasque, Vitoria

\section{REFERENCES}

ABARQuero, F.J. 2005: Cogotas I. La difusión de un tipo cerámico durante la Edad del Bronce (Valladolid).

ABARQUERO, F.J., BLANCO, A., ESPARZA, A. and RODRÍGUEZ, J.A. 2013: The central Iberian Meseta at the time of the Thera eruption: an overview. In MELLER, H., BERTEMES, F., BORK, H.-R. and RISCH, R. (eds.), $1600-$ Kultureller Umbruch im Schatten des Thera-Ausbruchs? (Halle), 115-26. 
ALduc, A. and Blondiaux, J. 2002: Mortalité maternelle et périnatalité au premier millénaire à Lisieux (Calvados, France). Bulletins et Mémoires de la Société d'Anthropologie de Paris 14 (3-4), 259-309.

ALEMÁN, I. BOTELLA, M.C. and RUIZ, L. 1997: Determinación del sexo en el esqueleto postcraneal. Estudio de una población mediterránea actual. Archivo Español de Morfología 2, 69-79.

ALFAYÉ, S.M. 2009: Sit tibi terra gravis: magical-religious practices against restless dead in the Ancient World. In MARCO, F., PINA, F. and REMESAL, J. (eds.), Formae mortis: el tránsito de la vida a la muerte en las sociedades antiguas (Barcelona), 181-216.

AMBRoSE, S.H. 1990: Preparation and characterization of bone and tooth collagen for isotopic analysis. Journal of Archaeological Science 17, 431-51.

AMBROSE, S.H. and NORR, L. 1993: Experimental evidence for the relationship of the carbon isotope ratios of whole diet and dietary protein to those of bone collagen and carbonate. In LAMBERT, J.B. and GRUPPE, G. (eds.), Prehistoric Human Bone: Archaeology at the Molecular Level (Berlin), 1-37.

ANDERson, K. 2011: Life Stages and Native Women. Memory, Teachings, and Story Medicine (Manitoba).

BONNET, D. 1988: Corps biologique, corps social: procréation et maladies de l'enfant en pays Mossi (Burkina Faso) (Paris).

BRONK RAMSEY, C. 2009: Bayesian analysis of radiocarbon dates. Radiocarbon 51(1), 337-60.

BROWN, T.A., NELSON, D.E., VOGEL, J.S. and SOUTHON, J.R. 1988: Improved collagen extraction by modified Longin method. Radiocarbon 30, 171-7.

BUIKSTRA, J.E. and UBELAKER, D.H. (eds.) 1994: Standards for Data Collection from Human Skeletal Remains (Fayetteville).

CASTRO, P.V., ChaPMAn, R.W., Gili, S., Lull, V., Micó, R. and RIHUETE, C. 1993-94: Tiempos sociales de los contextos funerarios agrarios. Anales de Prehistoria y Arqueología 9-10, 77-105.

CHISHOLM, B.S., NELSON, D.E. and SCHWARCZ, H.P. 1982: Stable carbon isotope ratios as a measure of marine versus terrestrial protein in ancient diets. Science 216, 1131-12.

CRUZ, C.B. and CoDinha, s. 2009: Death of mother and child due to dystocia in $19^{\text {th }}$ century Portugal. International Journal of Osteoarchaeology 20(4), 491-6.

DELIBES, G. 1978: Una inhumación triple de facies Cogotas I en San Román de Hornija (Valladolid). Trabajos de Prehistoria 35, 225-50.

DE MIGUEL, M.P. 2008: Gestantes en contextos funerarios altomedievales navarros. Lucentum XXVII, $233-42$.

DE NIRO, M.J. 1985: Postmortem preservation and alteration of in vivo bone collagen isotope ratios in relation to palaeodietary reconstruction. Nature 317, 806-9.

DUDAY, H. 2005: L'archéothanatologie ou l'archéologie de la mort. In DUTOUR, O., HUBLIN, J. and VANDERMERSCH, в. (eds.), Objets et méthodes en paléoanthropologie (Paris), 153-207.

ESPARZA, A. 1990: Sobre el ritual funerario de Cogotas I. Boletín del Seminario de Estudios de Arte y Arqueología LVI, 106-43.

ESPARZA, A., VELASCO, J. and DELIBES, G. 2012a: HUM 2005-00139: Planteamiento y primeros resultados de un proyecto de investigación sobre la muerte en Cogotas I. In RODRíGUEZ-MARCOS, J.A. and FERNÁNDEZManzano, J. (eds.), Cogotas I: Una cultura de la Edad del Bronce en la Península Ibérica (Valladolid), $259-320$.

ESPARZA, A., velasco, J. and DELibes, G. 2012b: Exposición de cadáveres en el yacimiento de Tordillos (Aldeaseca de la Frontera, Salamanca). Perspectiva bioarqueológica y posibles implicaciones para el estudio del ritual funerario de Cogotas. Zephyrus 69, 95-128.

FAHY, G., RICHARDS, M.P., RIEDEL, J., HUBLIN, J.J. and BOESCH, C. 2013: Stable isotope evidence of meat eating and hunting specialization in adult male chimpanzees. Proceedings of the National Academy of Sciences of the United States of America 110(15), 5829-33.

FERnÁndeZ, E. 2005: Polimorfismos de ADN mitocondrial en poblaciones antiguas de la cuenca mediterránea. (Unpublished Ph.D. thesis, Universidad de Barcelona) (http://www.tesisenred.net/ handle/10803/795).

GARRALDA, M.D. and GALERA, v. 1984: Los restos humanos de Los Tolmos de Caracena (Soria). In JiMENo, A., Los Tolmos de Caracena (Soria). Campañas de 1977, 1978 y 1979 (Madrid), 339-50.

HEDGES, R.E.M. and REYNARD, L.M. 2007: Nitrogen isotopes and the trophic level of humans in archaeology. Journal of Archaeological Science 34, 1240-51.

HEDGES, R.E.M., CLEMENT, J.G., THOMAS, C.D.L. and O'CONNELL, T.C. 2007: Collagen turnover in the adult femoral mid-shaft: modeled from anthropogenic radiocarbon tracer measurements. American Journal of Physical Anthropology 133, 808-16. 
IRIARTE, A. 2009: Morir de parto o el kalós thánatos en la Grecia arcaica y clásica. In MARCO, F., PINA, F. and REMESAl, J. (eds.), Formae mortis: el tránsito de la vida a la muerte en las sociedades antiguas (Barcelona), 13-24.

JIMENo, A. 1984: Los Tolmos de Caracena (Soria). Campañas de 1977, 1978 y 1979 (Madrid).

LEE-THORP, J.A. 2008: On isotopes and old bones. Archaeometry 50, 925-50.

LEWIS, M. 2007: The Bioarchaeology of Children. Perspectives from Biological and Forensic Anthropology (Cambridge).

LuLL, v. 1997-98: El Argar: la muerte en casa. Anales de Prehistoria y Arqueología 13-14, 65-80.

malgosa, A., Alesan, A., SAFont, S., Ballbé, M. and Ayala, M.M. 2004: A dystocic childbirth in the Spanish Bronze Age. International Journal of Osteoarchaeology 14, 98-103.

MARTÍNEZ-LABARGA, C. and RICKARDS, o. 1999: La utilización del DNA antiguo en la investigación de la historia evolutiva humana. Revista Española de Antropología Biológica 20, 195-213.

MINAGAWA, M. and WADA, E. 1984: Stepwise enrichment of $15 \mathrm{~N}$ along food chains: further evidence and the relation between $15 \mathrm{~N}$ and animal age. Geochimica et Cosmochimica Acta 48, 1135-40.

PALOMO-DíEZ, S., GOMES C., LÓPEZ-PARRA, AM., BAEZA-RICHER, C., ESPARZA-ARROYO, A. and ARROYO-PARDO, E. 2015 : Looking for a reliable criteria for the establishment of solid STR profiles using ancient critical samples from 3000 to 5000 years ago. Forensic Science International: Genetics Supplement Series 5, 78-80.

PALOMO-DÍEZ, S., ESPARZA-ARROYO, A., TIRADO-VIZCAÍNO, M., VELASCO-VÁZQUEZ, J., LÓPEZ-PARRA, A.M., GOMES, C., BAEZA-RICHER, C. and ARROYO-PARDO, E. (in preparation): Allelic dropout and kinship analysis: a correct forensic approach on an archaeological case.

PINHEIRO, J.o. 2006: Decay process of a cadaver. In SChMitT, A., CUNHA, E. and PINHEIRO, J. (eds.), Forensic Anthropology and Medicine: Complementary Sciences From Recovery to Cause of Death (Totowa), 85-116.

REIMER, P.J., BARD, E., BAYLISS, A., BECK, J.W., BLACKWELL, P.G., BRONK RAMSEY, C., ... VAN DER PLICHT, J. 2013: IntCal13 and Marine13 radiocarbon age calibration curves 0-50,000 Years cal BP. Radiocarbon 55(4), $1869-87$.

RICHARDS, M.P. and HEDGES, R.E.M. 1999: Stable isotope evidence for similarities in the types of marine foods used by Late Mesolithic humans at sites along the Atlantic coast of Europe. Journal of Archaeological Science 26, 122-31.

ROBERTS, J. 2011: Funerals and Fetish Interment in Accra, Ghana. In JINDRA, M. and NORET, J. (eds.), Funerals in Africa: Explorations of a Social Phenomenon (New York-Oxford), 207-26.

RODRíGUEZ-MARCOS, J. A. and FERNÁNDEZ-MANZANO, J. (eds.) 2012: Cogotas I. Una cultura de la Edad del Bronce en la Península Ibérica (Valladolid).

ROHLAND, N. and HOFReITER, M. 2007a: Ancient DNA extraction from bones and teeth. Nature Protocols 2(7), $1756-62$.

ROHLAND, N. and HOFREITER, M. 2007b: Comparison and optimization of ancient DNA extraction. BioTechniques $42(3), 343-52$.

ROHLAND, N., SIEDEL, H. and HOFREITER, M. 2009: A rapid column-based ancient DNA extraction method for increased sample throughput. Molecular Ecology Resources 10, 677-83.

SALAZAR-GARCíA, D.C., RICHARDS, M.P., NEHLICH O. and HENRY, A.G. 2014a: Dental calculus is not equivalent to bone collagen for isotope analysis: a comparison between carbon and nitrogen stable isotope analysis of bulk dental calculus, bone and dentine collagen from same individuals from the Medieval site of El Raval (Alicante, Spain). Journal of Archaeological Science 47, 70-7.

SALAZAR-GARCÍA, D.C., AURA, E., OLÀrIA C., TALAMO S., MORALES J.V. and RICHARDS M.P. 2014b: Isotope evidence for the use of marine resources in the Eastern Iberian Mesolithic. Journal of Archaeological Science $42,231-40$.

SCHEUER, L. and BLACK, S. 2000: Developmental Juvenile Osteology (San Diego).

SCHOELLER, D.A., 1999: Isotope fractionation: why aren't we what we eat? Journal of Archaeological Science $26,667-73$.

SCHOENINGER, M.J. and DE NIRO, M. 1984: Nitrogen and carbon isotopic composition of bone collagen from marine and terrestrial animals. Geochimica et Cosmochimica Acta 48, 625-39.

THOMAS, L.v. 1982: La mort africaine. Idéologie funeraire en Afrique noire (Paris).

TUREK, J. 2011: Age and gender identities and social differentiation in the central European Copper Age. In Amundsen-meyer, L., engel, n. and PICKering, s. (eds.), Identity Crisis: Archaeological Perspectives on Social Identity (Calgary), 49-61. 
VAN DER MERWE, N.J. and VOGEL, J.C. 1978: 13C content of human collagen as a measure of prehistoric diet in woodland North America. Nature 276, 815-16.

VAN KLINKEN, G.J. 1999: Bone collagen quality indicators for palaeodietary and radiocarbon measurements. Journal of Archaeological Science 26, 687-95.

WEISS-KREJCI, E. 2011: The formation of mortuary deposits: implications for understanding mortuary behavior of past populations. In Agarwal, s.C. and Glencross, B.A. (eds.), Social Bioarchaeology (Chichester), 68-106.

WILLIS, A. and oxenham, M. 2011: A case of maternal and perinatal death in Neolithic Southern Vietnam, c. 2100-1050 BCE. International Journal of Osteoarchaeology 23(6), 676-84. 